\title{
Circadian blood pressure profile in patients with chronic kidney disease stage 1-3
}

\author{
Agnieszka Pluta', Paweł Stróżecki², Jacek Manitius² \\ 'Department of Community Nursing, Faculty of Health Sciences, The Nicolaus Copernicus University in Toruń \\ ${ }^{2}$ Department of Nephrology, Hypertension and Internal Medicine, Faculty of Medicine, The Nicolaus Copernicus University in Toruń
}

\section{Summary}

Background The population of patients with chronic kidney disease (CKD) is prone to high cardiovascular morbidity and mortality. Aberrant circadian pattern of blood pressure is associated with increase cardiovascular risk. The study investigated circadian blood pressure profile in patients with early stages of CKD.

Material and methods The study included 90 patients with CKD stage 1-3, aged 34-79 years and 30 healthy volunteers as control group. All patients underwent ambulatory blood pressure monitoring (ABPM). Patient was classified as "dipper" if relative decreases in SBP and DBP at night was at least 10\%. If the drop the SBP or DBP was less than $10 \%$ patient was classified as "non-dipper".

Results Hypertension was present in $78.9 \%$ of patients with CKD stage 1-3. "Non-dipper" profile was found in $59(66 \%)$ of the surveyed patients with CKD, namely in $16(53 \%)$ in CKD stage $1,23(70 \%)$ in CKD stage 2, and $20(74 \%)$ in CKD stage 3. "Non-dipper" profile was observed in $9(30 \%)$ of control patients. In the whole study population $(n=120)$ significant positive correlation was found between $\%$ drop in SBP and eGFR $(r=0.25$; $p<0.01)$. There was no significant correlation between $\%$ drop in SBP and eGFR $(r=0.12 ; p=0.26)$ in 90 CKD patients. There was statistically significant negative correlation between \% drop in SBP and age $(r=-0.25 ; \mathrm{p}<0.05)$ and BMI $(\mathrm{r}=-0.24 ; \mathrm{p}<0.05)$.

Conclusions "Non-dipper" profile is a common finding among patients with early stages of CKD and may be associated with a higher cardiovascular risk. ABPM should be a standard procedure in patients with $\mathrm{CKD}$, even in early stages of the disease.

key words: chronic kidney disease, dipper, non-dipper, circadian blood pressure profile

Arterial Hypertens. 2015, vol. 19, no. 4, pages: 187-193

DOI: $10.5603 / A H .2015 .0023$

\section{Background}

Blood pressure is characterized by a circadian rhythm. The analysis of the circadian blood pressure profile is possible by the-24-hour ambulatory blood pressure monitoring (ABP). The lowest blood pressure values are observed at about 3 am (between 2 and $3 \mathrm{am}$ ) and a slight increase in blood pressure is observed before waking states. Then there is a sudden increase

\footnotetext{
Address for correspondence: Agnieszka Pluta

Department of Community Nursing, Faculty of Health Sciences, The Nicolaus Copernicus University in Toruń

ul. Łukasiewicza 1, 85-801, Bydgoszcz, Poland

tel.: +48525855811

e-mail: agnieszkapluta@poczta.onet.pl
}

V M Copyright $@ 2015$ Via Medica, ISSN 2449-6170 
in blood pressure after waking hours in the morning, with the highest value at about 9 o'clock and a slight physiological decrease of values at noon and the rebound in the afternoon and evening. This circadian rhythm occurs in people with normal blood pressure and in the majority of patients with essential hypertension [1]. The population of patients with chronic kidney disease (CKD) exhibited the presence of a disturbed circadian blood pressure profile - one of the risk factors of blood pressure related target organ damage [2-8]. The aim of the study was to analyse the circadian pattern of blood pressure in patients in the early stages of chronic kidney disease.

\section{Material and methods}

The study was performed between September 2012 and November 2014, after getting the approval from the Bioethics Committee at the Nicolaus Copernicus University Collegium Medicum in Bydgoszcz. Written consent was obtained from all patients included in the study.

Subjects for the research were recruited based on a review of medical history of patients treated at the Nephrology Outpatient Clinic of the University Hospital No.1 in Bydgoszcz.

The study group consisted of 90 patients with CKD stage 1-3. Patients with diabetes were not included in the study group. Forty patients refused to participate in the study. In all subjects blood was sampled for serum creatinine and glomerular filtration rate (EGFR) was estimated using CKD-EPI equation [9]. Based on eGFR patients were classified as CKD stage 1 (30 patients), CKD stage 2 (33 patients) and CKD stage 3 (27 patients).

The causes of CKD in the studied patient population were as follows: biopsy-proven chronic glomerulonephritis $(\mathrm{n}=16 ; 17.7 \%)$, hypertensive nephropathy $(\mathrm{n}=3 ; 3.3 \%)$, polycystic kidney disease $(\mathrm{n}=29 ; 32.2 \%)$, gouty nephropathy $(\mathrm{n}=5 ; 5.5 \%)$, nephrolithiasis $(\mathrm{n}=23 ; 25.5 \%)$, history of unilateral nephrectomy due to pyonephrosis, trauma or tumour $(\mathrm{n}=3 ; 3.3 \%)$. In $11(12.2 \%)$ cases the cause of CKD remained unknown.

The control group consisted of 30 individuals without hypertension, obesity, diabetes, CKD and with normal creatinine concentration in blood serum.

Each patient underwent a clinical assessment which included the measurement of arterial blood pressure (BP) and the calculation of body mass index (BMI). Systolic (SBP) and diastolic blood pressure $(\mathrm{DBP})$ were measured using the $\mathrm{A} \& \mathrm{D}$ Medical
UA-631 automatic blood pressure monitor. Subsequently, mean arterial pressure (MAP) was calculated from the formula MAP $=\mathrm{DBP}+1 / 3(\mathrm{SBP}-\mathrm{DBP})$ $(\mathrm{mm} \mathrm{Hg})$ and pulse pressure $(\mathrm{PP})$ was calculated from the formula PP = SBP-DBP $(\mathrm{mm} \mathrm{Hg})$.

Each of the studied patients was subjected to 24-hour ambulatory blood pressure monitoring (ABPM) using the A\&D TM2430 device. Cuff size was adapted to a patient's arm circumference and the patients were instructed on the operation principles of the apparatus. BP measurements were taken every 30 minutes. The period between $6 \mathrm{am}$ and $10 \mathrm{pm}$ was considered day hours, and the period between $10 \mathrm{pm}$ and 6 am was considered night hours. Subsequently, mean values of SBP and DBP from the period of the day and night were analysed. The percentage drop in blood pressure was calculated by the following equation: $\%$ drop in SBP $=$ [(SBP day - SBP night $) / S B P$ day $]$ $\mathrm{x} 100 \%$

Similarly, \% drop in diastolic blood pressure was calculated. If the \% drop in SBP and DBP was at least $10 \%$ the patient was qualified as a "dipper", but if it was less than $10 \%$, patients were classified as "non-dipper" [10]. Data on the duration of hypertension and antihypertensive treatment were obtained during the interview and from the patients' charts.

\section{Statistical analysis}

The results obtained during the study were analysed statistically using the STATISTICA PL 7.0. For comparison of results in more than two groups non-parametric ANOVA test was used. Data are presented as mean \pm standard deviation (SD). The level of statistical significance was set at $\mathrm{p}<0.05$.

\section{Results}

The characteristics of the study group of patients with $\mathrm{CKD}$ stage $1-3$ and the control group are shown in the Table I.

With progress of CKD the number of "non-dippers" increases (Figure 1).

Table II shows comparison of selected clinical parameters in patients with CKD stages 1, 2 and 3 compared with the control group. With the progress of CKD the number of patients characterized by the feature "dipper" ( $p<0.001)$ decreased.

In the study hypertension was found in in $56.7 \%$ of patients in stage $1 \mathrm{CKD}$, in $84.9 \%$ of patients in stage $2 \mathrm{CKD}$ and in $96.3 \%$ of patients in stage 3 $\mathrm{CKD}$. The duration of hypertension was statistical- 
Table I. Characteristics of the studied groups of patients with CKD1-CKD3 with the control group

\begin{tabular}{|c|c|c|c|}
\hline Parameter & $\begin{array}{c}\text { Control (C) } \\
(\mathrm{n}=30)\end{array}$ & $\begin{array}{c}\text { CKD 1-CKD } 3 \\
(n=90)\end{array}$ & $\mathbf{P}$ \\
\hline Age (years) & $54 \pm 11$ & $56 \pm 11$ & 0.27 \\
\hline Gender women/men & $19 / 11$ & $41 / 49$ & NS \\
\hline BMI $\left[\mathrm{kg} / \mathrm{m}^{2}\right]$ & $25 \pm 3.1$ & $27 \pm 3.9$ & $<0.001$ \\
\hline SBP ABPM [mm Hg] & $123 \pm 10$ & $126 \pm 14$ & 0.15 \\
\hline DBP ABPM [mm Hg] & $74 \pm 5$ & $76 \pm 9$ & 0.15 \\
\hline MAP ABPM [mm Hg] & $91 \pm 6$ & $92 \pm 10$ & 0.39 \\
\hline PP ABPM [mm Hg] & $49 \pm 7$ & $51 \pm 9$ & 0.38 \\
\hline SBP ABPM day [mm Hg] & $131 \pm 10$ & $131 \pm 14$ & 0.99 \\
\hline DBP ABPM day [mm Hg] & $79 \pm 5$ & $80 \pm 9$ & 0.72 \\
\hline MAP ABPM day [mm Hg] & $96 \pm 6$ & $96 \pm 11$ & 1.00 \\
\hline PP ABPM day [mm Hg] & $52 \pm 7$ & $52 \pm 10$ & 0.98 \\
\hline SBP ABPM night [mm Hg] & $112 \pm 12$ & $121 \pm 15$ & $<0.005$ \\
\hline DBP ABPM night [mm Hg] & $67 \pm 7$ & $72 \pm 9$ & $<0.05$ \\
\hline MAP ABPM night [mm Hg] & $81 \pm 8$ & $87 \pm 11$ & $<0.005$ \\
\hline SBP ABPM day — SBP ABPM night (mm Hg) & $18.6 \pm 7.9$ & $10.0 \pm 10.5$ & $<0.00001$ \\
\hline DBP ABPM day — DBP ABPM night (mm Hg) & $12.4 \pm 6.5$ & $8.0 \pm 10.5$ & $<0.005$ \\
\hline$\%$ drop in SBP ABPM [mm Hg] & $14.2 \pm 5.9$ & $8.0 \pm 7.7$ & $<0.00001$ \\
\hline \% drop in DBP ABPM [mm Hg] & $15.5 \pm 7.8$ & $10.0 \pm 8.8$ & $<0.0002$ \\
\hline Dippers n(\%) & $21(70 \%)$ & $31(34 \%)$ & $<0.005$ \\
\hline $\mathrm{SBP}[\mathrm{mm} \mathrm{Hg}]$ & $132 \pm 15$ & $137 \pm 15$ & 0.18 \\
\hline $\mathrm{DBP}[\mathrm{mm} \mathrm{Hg}]$ & $80 \pm 9$ & $84 \pm 9$ & $<0.05$ \\
\hline MAP [mm Hg] & $98 \pm 9$ & $102 \pm 9$ & $<0.05$ \\
\hline eGFR CKD-EPI (ml/min/1,73 m²) & $95.93 \pm 15.0$ & $74.77 \pm 23.69$ & $<0.0001$ \\
\hline Creatinine [mg/dl] & $0.76 \pm 0.20$ & $1.06 \pm 0.36$ & $<0.0001$ \\
\hline
\end{tabular}

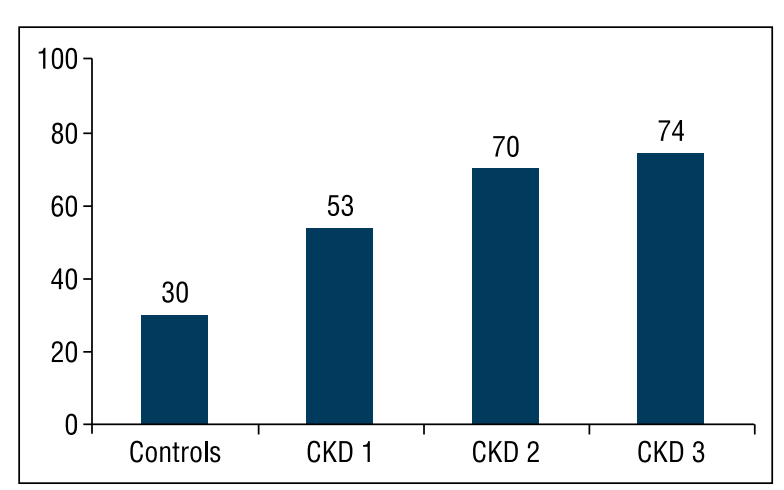

Figure 1. Prevalence of "non-dipper" blood pressure profile in investigated groups

ly significantly higher for patients in stage $3 \mathrm{CKD}$ when compared to patients in stage 1 and 2 of CKD $(\mathrm{p}<0.001, \mathrm{p}<0.05$, respectively). The stage of CKD increased number of antihypertensive medications, as follows: in stage one CKD median was 1.0 (range
$0-4)$ in stage two CKD - 1.0 (range 0-5) and in stage three CKD -2.0 (range 0-5).

In the whole population $(\mathrm{n}=120)$ a significant positive correlation between \% drop in SBP ABPM and eGFR was found $(\mathrm{r}=0.25 ; \mathrm{p}<0.01)$ (Figure 2) and statistically significant negative correlations between \% drop in SBP ABPM and age $(r=-0.25 ; \mathrm{p}<$ $0.05)$, BMI $(r=-0.30 ; p<0.05)$. Similar correlations were demonstrated for the difference SBP ABPM day and night: a statistically significant positive correlation with eGFR $(r=0.25 ; \mathrm{p}<0.01)$ and statistically significant negative correlation with age $(\mathrm{r}=-0.25 ; \mathrm{p}$ $<0.01)$, BMI $(\mathrm{r}=-0.30 ; \mathrm{p}=0.001)$. In this population a negative correlation of \% drop in DBP ABPM with BMI $(r=-0.26 ; \mathrm{p}<0.01)$ and negatively correlated difference in DBP ABPM day and DBP ABPM night with $\mathrm{BMI}(\mathrm{r}=-0.24 ; \mathrm{p}<0.01)$ were indicated. On the other hand, in 90 patients with CKD there was no significant correlation between GFR and \% drop in SBP ABPM $(r=0.12 ; p=0.26)$. However, 
Table II. Characteristics of the studied groups of patients with CKD1, CKD2 and CKD3 with the control group

\begin{tabular}{|c|c|c|c|c|c|}
\hline Parameter & $\begin{array}{c}\text { Control (C) } \\
(\mathrm{n}=30)\end{array}$ & $\begin{array}{c}\text { CKD } 1 \\
(n=30)\end{array}$ & $\begin{array}{c}\text { CKD } 2 \\
(n=33)\end{array}$ & $\begin{array}{c}\text { CKD } 3 \\
(n=27)\end{array}$ & $\begin{array}{c}\text { ANOVA } \\
\mathbf{P}\end{array}$ \\
\hline Age (years) & $54 \pm 11$ & $50 \pm 11$ & $57 \pm 11$ & $63 \pm 7$ & $<0.05$ \\
\hline Gender women/men & $19 / 11$ & $14 / 16$ & $16 / 17$ & $11 / 16$ & \\
\hline BMI $\left[\mathrm{kg} / \mathrm{m}^{2}\right]$ & $24.8 \pm 3.1$ & $26.5 \pm 4.0$ & $27.4 \pm 4.07$ & $27.8 \pm 4.0$ & 0.05 \\
\hline SBP ABPM [mm Hg] & $123 \pm 10$ & $124 \pm 11$ & $125 \pm 13$ & $131 \pm 16$ & 0.085 \\
\hline DBP ABPM [mm Hg] & $74 \pm 5$ & $75 \pm 8$ & $75 \pm 8$ & $77 \pm 9$ & 0.45 \\
\hline MAP ABPM [mm Hg] & $91 \pm 6$ & $91 \pm 9$ & $90 \pm 10$ & $95 \pm 11$ & 0.28 \\
\hline PP ABPM [mm Hg] & $49 \pm 7$ & $48 \pm 6$ & $50 \pm 8$ & $54 \pm 12$ & 0.07 \\
\hline SBP ABPM day [mm Hg] & $131 \pm 10$ & $129 \pm 12$ & $129 \pm 13$ & $135 \pm 16$ & 0.07 \\
\hline DBP ABPM day [mm Hg] & $79 \pm 5$ & $79 \pm 10$ & $79 \pm 8$ & $81 \pm 10$ & 0.67 \\
\hline MAP ABPM day [mm Hg] & $96 \pm 6$ & $94 \pm 12$ & $96 \pm 9$ & $99 \pm 11$ & 0.37 \\
\hline PP ABPM day [mm Hg] & $52 \pm 7$ & $49 \pm 7$ & $52 \pm 11$ & $54 \pm 12$ & 0.38 \\
\hline SBP ABPM night [mm Hg] & $112 \pm 12$ & $117 \pm 12$ & $120 \pm 15$ & $127 \pm 17$ & $<0.001$ \\
\hline DBP ABPM night [mm Hg] & $67 \pm 7$ & $71 \pm 8$ & $70 \pm 10$ & $74 \pm 9$ & $<0.05$ \\
\hline MAP ABPM night [mm Hg] & $81 \pm 8$ & $86 \pm 9$ & $86 \pm 11$ & $91 \pm 11$ & $<0.001$ \\
\hline SBP ABPM day — SBP ABPM night [mm Hg] & $18.6 \pm 7.9$ & $11.6 \pm 11.1$ & $9.9 \pm 10.7$ & $8.3 \pm 9.6$ & $<0.001$ \\
\hline DBP ABPM day — DBP ABPM night [mm Hg] & $12.4 \pm 6.5$ & $8.2 \pm 8.4$ & $8.8 \pm 6.4$ & $7.5 \pm 7.9$ & 0.052 \\
\hline$\%$ drop in SBP ABPM [mm Hg] & $14.2 \pm 5.9$ & $8.7 \pm 8.2$ & $7.6 \pm 7.9$ & $6.1 \pm 7.1$ & $<0.0001$ \\
\hline \% drop in DBP ABPM [mm Hg] & $15.5 \pm 7.8$ & $9.8 \pm 9.8$ & $11.1 \pm 7.9$ & $8.8 \pm 8.9$ & $<0.05$ \\
\hline Dippers n(\%) & $21(70 \%)$ & $14(47 \%)$ & $10(30 \%)$ & $7(26 \%)$ & $<0.001$ \\
\hline SBP [mm Hg] & $132 \pm 15$ & $136 \pm 14$ & $135 \pm 14$ & $141 \pm 16$ & 0.17 \\
\hline $\mathrm{DBP}[\mathrm{mm} \mathrm{Hg}]$ & $80 \pm 9$ & $86 \pm 9$ & $83 \pm 10$ & $84 \pm 6$ & 0.07 \\
\hline MAP [mm Hg] & $98 \pm 9$ & $103 \pm 10$ & $100 \pm 9$ & $103 \pm 8$ & 0.11 \\
\hline $\mathrm{PP}[\mathrm{mm} \mathrm{Hg}]$ & $52 \pm 13$ & $50 \pm 9$ & $51 \pm 13$ & $58 \pm 15$ & 0.16 \\
\hline eGFR CKD-EPI [ml/min/1,73 m²] & $95.93 \pm 15.0$ & $101.42 \pm 9.45$ & $74.47 \pm 8.98$ & $46.36 \pm 8.07$ & $<0.0001$ \\
\hline Creatinine $[\mathrm{mg} / \mathrm{dL}]$ & $0.76 \pm 0.20$ & $0.75 \pm 0.17$ & $0.99 \pm 0.16$ & $1.47 \pm 0.29$ & $<0.0001$ \\
\hline
\end{tabular}

Description of abbreviations listed in table is provided in the text.

statistically significant negative correlation was found between \% drop in SBP ABPM: age $(\mathrm{r}=-0.25 ; \mathrm{p}<$ 0.05), BMI $(\mathrm{r}=-0.24 ; \mathrm{p}<0.05)$.

In multivariate analysis \% drop in SBP ABPM is significantly correlated with age $(r=0.049)$, BMI $(r=0.039)$, eGFR $(r=0.844)$. Multiple analytical results are shown in Table III.

\section{Discussion}

In recent years, ambulatory blood pressure monitoring (ABPM) was widely used in diagnosing patients with hypertension. Blood pressure values obtained by ABPM, better than casual measurements, correlate with organ damage of hypertension [11-13]. With

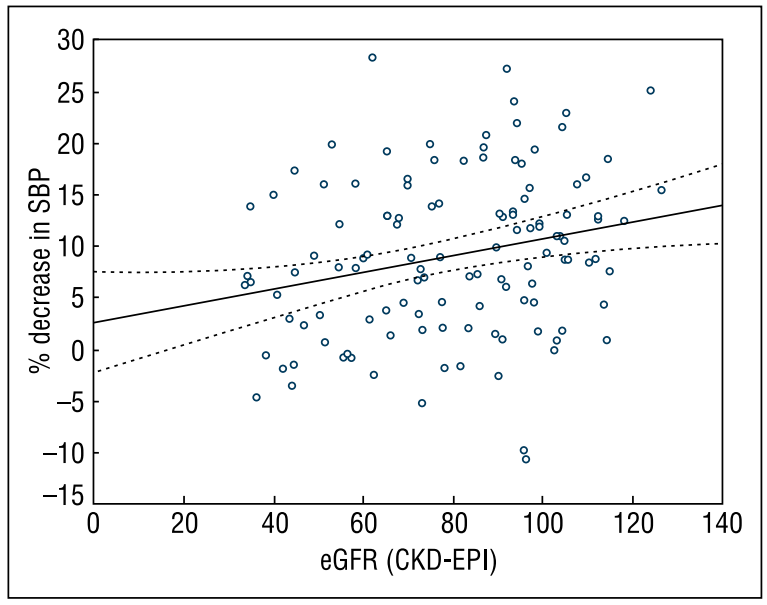

Figure 2. Correlation between \% drop in SBP ABPM and eGFR (CKD-EPI) 
Table III. Results of multiple linear regression analysis with \% drop in SBP ABPM as a dependent variable (Model 1)

\begin{tabular}{l|l|l}
\hline \multicolumn{2}{l}{ Model 1} \\
\hline$R=0.33 ; R^{2}=0.11 ;$ \\
$F=3.53 ; p<0.02$
\end{tabular}

the twenty-four hour blood pressure monitoring it has become possible to analyse the circadian blood pressure profile.

CKD is a syndrome which on one hand increases the morbidity and mortality of cardiovascular disease [14] and on the other hand the presence of other cardiovascular diseases accelerates the progression of renal disease [15]. Complications of the cardiovascular system are the leading cause of death in the population of CKD patients $[14,16]$. The high morbidity and cardiovascular mortality in chronic kidney disease is due to the accumulation of cardiovascular risk factors. Among these factors, traditional factors such as inter alia hypertension, diabetes, smoking and non-traditional factors associated with the progression of CKD are mentioned. To the latter group among other factors, chronic inflammation, hypervolemia, oxidative stress, elevated levels: asymmetric dimethylarginine, parathyroid hormone, endothelin, homocysteine, and excessive activity of the sympathetic nervous system are included $[17,18]$. In the present study hypertension as a risk factor for increased morbidity and mortality of cardiovascular disease concerned $78.9 \%$ of patients with CKD stages 1-3.

As already mentioned, the ambulatory blood pressure monitoring is used in assessing cardiovascular risk due to the ability to analyse the profile of pressure circadian rhythm. Among patients with kidney disease there is a tendency to lack of nocturnal fall in blood pressure [19]. The results of this study indicate the presence of "non-dipper" profile in $66 \%$ of patients with chronic kidney disease stage 1-3. In this group, $57 \%$ had hypertension. In other studies, the percentage of patients with CKD stage 1-3 in whom a "non-dipper" profile was determined is equal to $41-46 \%[7,8]$, and $41-78.5 \%$ of patients with eGFR $<60 \mathrm{ml} / \mathrm{min} / 1.73 \mathrm{~m}^{2}[5,20-22]$. In the group of untreated patients immediately after the diagnosis of primary chronic glomerulonephritis an abnormal circadian rhythm was found in $70 \%$ of patients [23]. In the present study a "non-dipper" profile was indicated in $30 \%$ of the control group. In other works this percentage ranged from $17 \%$ to $57 \%[24,25]$. There are many reasons that can be responsible for the presence of the disadvantageous "non-dipper" profile in the population of patients with CKD. These can be, among others, the increased activity of the sympathetic nervous system as a result of impulses from afferent fibres innervating the kidney, water balance disorders, disturbances in the secretion of adrenal hormones as well as parenchymal kidney damage [19, 26-29].

Regardless of the mechanism of disorders in the circadian rhythm of blood pressure, patients without a nocturnal drop in pressure are characterized by a higher incidence of organ complications [30, 31]. Patients with chronic kidney disease despite good control of blood pressure during the day may be at risk for cardiovascular complications caused by night hypertension [32].

Ishikawa et al. during 41 months observed 811 patients over 60 years old with hypertension including: 537 with CKD and 274 without CKD [5]. Analysing the circadian blood pressure profile they distinguished: "non-dippers", "dippers" and "extreme dippers" (extreme dippers been defined as an indicator of the SBP pressure measured during sleep/SBP measured at the time of the activity of $<0.8$ ). They showed that patients with CKD during observation regardless of whether the circadian rhythm was characteristic for "dippers" or "non-dippers" were saddled with an increased risk of cardiovascular events (non-dippers: hazard ratio [HR], 2.16; 95\% confidence interval $[\mathrm{CI}], 1.19-3.91$; extreme dippers: HR, 2.38; 95\% CI, 1.17-4.83). Patients with CKD were characterized by an increased risk of cardiovascular events. Ishikawa et al. thought that CKD and other cardiovascular risk factors explain the increased risk in patients characterized as "non-dippers", but do not explain the increased risk in the group of "extreme dippers". In turn, another group of research [33] examining patients with CKD stage 1-4 which constituted of $38 \%$ of patients with diabetes and $83 \%$ with dyslipidaemia demonstrated that the group of patients with CKD stage 3-4 was characterized by more frequent occurrence of disturbed circadian rhythms than those in the initial stage of CKD ( $p=0.018)$. The authors found out that CKD is the only feature that significantly affects the circadian blood pressure profile in the study group. The "non-dipper" profile of blood pressure in patients with CKD is associated with a hazard ratio of 2.5 for cardiovascular events and 9.6 for death from these causes [34]. 
The presence of "non-dipper" profile of blood pressure and left ventricular hypertrophy are predisposing factors for the development of CKD in patients with hypertension, without diabetes [7, 35]. This indicates a need to monitor the condition of heart and blood pressure circadian profile as soon as diagnosis of chronic renal disease is made, especially if the patient is hypertension. In the population of patients with hypertension in which the "non-dipper" profile of blood pressure feature dominates, especially if the eGFR is $<60 \mathrm{ml} / \mathrm{min} / 1.73 \mathrm{~m}^{2}$ pharmacologic therapy is vitally important [21]. It aims to reduce the risk of cardiovascular complications associated with uncontrolled blood pressure values and the consequences of impaired circadian rhyme. The action of the ACE inhibitor and the angiotensin receptor blocker apart from their antihypertensive activity exhibit a nephroprotective effect. Moreover, in a population of patients with CKD they partially block the sympathetic nervous system which is responsible for the disadvantageous "non-dipper" profile [36]. No drop in blood pressure at night may be a consequence of an autonomic dysfunction in the early stages of CKD.

Statistically significant positive correlation between \% drop in SBP ABPM and eGFR $(r=0.25$; $\mathrm{p}<0.01)$ demonstrated in this study for the general population $(\mathrm{n}=120)$ may indicate the significance of deterioration of renal function on the normal regulation of blood pressure. Luck of this dependence in patients with CKD can be explained by reduced number of patients enrolled in the study, but may also result from failure to analyse patients with more advanced CKD (stage 4 and stage 5).

In the multivariate analysis of the \% drop in SBP ABPM age, BMI and eGFR were analysed as independent variables. This model explained only $11 \%$ of the variability of $\%$ drop in SBP ABPM. This means that the variability of this feature is dependent on many factors which are not analysed in the present study. These factors include the concentration of albumin in the blood serum, proteinuria, activation of the sympathetic nervous system $[22,37,38]$.

It must be concluded that the vast majority of patients with stage $1-3 \mathrm{CKD}$ is characterized by "non-dipper" profile. Data from recent years show that patients with hypertension characterized as "non-dippers" are burdened with a higher risk of cardiovascular events [13]. Evaluation of circadian blood pressure profile may identify CKD patients at high risk of complications of the cardiovascular system.

\section{Conclusions}

"Non-dipper" profile is a common finding among patients in the early stages of CKD and may be associated with a higher cardiovascular risk. ABPM should be a standard procedure in patients with $\mathrm{CKD}$, even in early stages of the disease.

\section{Streszczenie}

Wstęp Populacja chorych z CKD charakteryzuje się wysoką chorobowością i śmiertelnością sercowo-naczyniową. Ta grupa pacjentów charakteryzuje się zaburzonym dobowym profilem ciśnienia tętniczego, a cecha ta może zwiększać ryzyko sercowo-naczyniowe. Celem pracy była analiza dobowego rytmu ciśnienia tętniczego u pacjentów we wczesnych stadiach CKD. Materiał i metody Badaniem objęto 90 chorych w 1-3 stadium CKD w wieku 34-79 lat oraz 30 osób w wieku 38-79 lat stanowiących grupę kontrolną. U wszystkich badanych przeprowadzono ambulatoryjne monitorowanie ciśnienia tętniczego (ABPM). Jeśli względne obniżenie SBP i DBP w nocy wynosiło co najmniej 10\% pacjenta kwalifikowano jako „dipper”, natomiast jeśli spadek SBP i DBP był mniejszy niż 10\% pacjenta kwalifikowano jako „non-dipper”.

Wyniki Nadciśnienie tętnicze występowało u 78,9\% pacjentów z CKD w stadium 1-3. Profil „non-dipper” stwierdzono u 59 (66\%) spośród badanych chorych z CKD, w tym w stadium 1 CKD u 16 (53\%), w stadium 2 CKD u $23(70 \%)$ oraz u $20(74 \%)$ w stadium 3 CKD. W grupie kontrolnej profil non-dipper stwierdzono u $9(30 \%)$ pacjentów. W badanej catej populacji $(\mathrm{n}=120)$ stwierdzono znamienną statystycznie dodatnią korelację między \% spadkiem SBP i eGFR $(\mathrm{r}=0,25 ; \mathrm{p}<0,01)$. W grupie 90 pacjentów z CKD nie wykazano korelacji między eGFR $\%$ spadkiem SBP $(r=0.12 ; p=0.26)$. Występowały natomiast znamienne statystycznie ujemne korelacje $\%$ spadku nocnego SBP z: wiekiem $(\mathrm{r}=-0,25 ; \mathrm{p}<0,05)$ oraz BMI $(\mathrm{r}=-0,24 ; \mathrm{p}<0,05)$.

Wnioski Wśród pacjentów z CKD w stadium 1-3 częściej występuje cecha "non-dipper" co może się wiązać z wyższym ryzykiem incydentów sercowo-naczyniowych w tej grupie chorych. ABPM powinno być standardowym postępowaniem u pacjentów z CKD, nawet w jej wczesnych stadiach.

słowa kluczowe: przewlekła choroba nerek, dipper, non-dipper, dobowy profil ciśnienia tętniczego 


\section{References}

1. Małyszko J., Zbroch E., Małyszko J., Myśliwiec M. Morning surge in blood pressure. Forum Medycyny Rodzinnej 2012; 6: 115-120.

2. Wang C, Zhang J., Liu X. et al. Reversed Dipper Blood-Pressure Pattern Is Closely Related to Severe Renal and Cardiovascular Damage in Patients with Chronic Kidney Disease. PLoS One. 2013; 8: 55419-55428.

3. Farmer C.K., Goldsmith D.J., Cox J., Dallyn P., Kingswood J.C., Sharpstone $\mathrm{P}$. An investigation of the effect of advancing uraemia, renal replacement therapy and renal transplantation on blood pressure diurnal variability. Nephrol. Dial. Transplant. 1997; 12: 2301-2307.

4. Mojón A., Ayala D.E., Piñeiro L. et al. Comparison of ambulatory blood pressure parameters of hypertensive patients with and without chronic kidney disease. Chronobiol. Int. 2013; 30: 145-158

5. Ishikawa J., Hoshide S., Eguchi K., Shimada K., Kario K. Cardiovascular Risks of Dipping Status and Chronic Kidney Disease in Elderly Japanese Hypertensive Patients. J. Clin. Hypertens. (Greenwich). 2008; 10: 787-794

6. Lekakis J.P., Zakopoulos N.A., Protegorou A.D. et al. Arterial stiffness assessed by pulse wave analysis in essential hypertension: relation to 24-h blood pressure profile. Int. J. Cardiol. 2005; 102: 391-395.

7. Hye Rim An, Sungha Park, Tae-Hyun Yoo et al. Non-Dipper Status and Left Ventricular Hypertrophy as Predictors of Incident Chronic Kidney Disease. J. Korean Med. Sci. 2011; 26: 1185-1190

8. Feldstein C., Akopian M., Olivieri A.O., Garrido D. Association Between Nondipper Behavior and Serum Calcium in Hypertensive Patients with Mild-to-Moderate Chronic Renal Dysfunction. Clinical and Experimental Hypertension 2012; 34: 417-423.

9. Levey A.S., Stevens L.A., Schmid C.H. et al. A new equation to estimate glomerular filtration rate. Ann. Intern. Med. 2009; 150: 604-612.

10. Verdecchia P., Schillaci G., Guerrieri M. et al. Circadian blood pressure changes and left ventricular hypertrophy in essential hypertension. Circulation 1990; 81: 528-536.

11. Lewandowski J. Przydatność całodobowego pomiaru ciśnienia tętniczego w codziennej praktyce lekarskiej. Przew. Lek. 2008; 6: 47-52.

12. Agarwal R. Ambulatory blood pressure and cardiovascular events in chronic kidney disease. Semin. Nephrol. 2007; 27: 538-543.

13. Sinha A.D., Agarwal R. The complex relationship between CKD and ambulatory blood pressure patterns. Adv. Chronic Kidney Dis. 2015; 22: 102-107 [Abstract].

14. Go A.S, Chertow G.M., Fan D., McCulloch C.M., Hsu C. Chronic Kidney Disease and the Risks of Death, Cardiovascular Events, and Hospitalization. N. Engl. J. Med. 2004; 351: 1296-1305

15. Levin A., Djurdjev O., Barrett B. et al. Cardiovascular Disease in patients with chronic kidney disease: getting to heart of the matter. Am. J. Kidney Dis. 2001; 38: 1398-1407.

16. Raphael K.L., Wei G., Greene T., Baird B.C., Beddhu S. Cognitive function and the risk of death in chronic kidney disease. Am. J. Nephrol. 2012; 35: 49-57.

17. Vanholder R., Massy Z., Argiles A., Spasovski G., Vebeke F., Lameire N. European Uremic Toxin Work Group. Chronic kidney disease as cause of cardiovascular morbidity and mortality. Nephrol. Dial. Transplant. 2005; 20: 1048-1056.

18. Chue C.D., Townend J.N., Steeds R.P., Ferro C.J. Arterial stiffness in chronic kidney disease: causes and consequences. Heart 2010; 96: $817-882$

19. Czarnecka D., Styczkiewicz K., Kawecka-Jaszcz K. Ambulatory Blood Pressure Monitoring in Special Groups. Arterial Hypertens. 2003; 7: 207-217.
20. Pogue V., Rahman M., Lipkowitz M. et al. Disparate Estimates of Hypertension Control From Ambulatory and Clinic Blood Pressure Measurements in Hypertensive Kidney Disease. Hypertension. 2009; 53: 20-27.

21. Aparci M., Kardesoglu E., Zafer I., Yiginer O., Uz O., Demirbolat C. Blood pressure control and dipping status in hypertensive patients with mild renal dysfunction. LOOD. Anatol. J. Clin. Investig. 2009; 3: 123-126.

22. Elung-Jensen T., Strandgaard S., Kamper A.L. Longitudinal observations on circadian blood pressure variation in chronic kidney disease stages 3-5. Nephrol. Dial. Transplant. 2008; 23: 2873-2878.

23. Łochyńska K., Oko A., Idasiak-Piechocka I., Czekalski S. Dobowy rytm ciśnienia tętniczego u chorych we wczesnym okresie pierwotnego przewlekłego kłębuszkowego zapalenia nerek. Arterial Hypertens. 2003; 7: 7-14.

24. Korkmaz S., Yilmaz A. Yildiz G., Kiliçli F., Içağasioğlu S. Relationship between homocysteine and non-dipper pattern in patients with type 2 diabetes mellitus. Arq. Bras. Endocrinol. Metab. 2012; 56: $285-290$.

25. Paezmtsac O.B., Cervino C., Puleio P., et al. Morning hypertension and non-dipper behavior in pregnant women with white coat syndrome. Rev. Argent. Cardiol. 2015; 83: 119-123.

26. Redon J., Zaragoza M.D., Oliver V., Galindo M.J. Ambulatory blood pressure and the kidney. Blood Press. Monit. 1998; 3: 157-161.

27. Cohen D.L., Huan Y., Townsend R.R. Ambulatory Blood Pressure in Chronic Kidney Disease. Curr. Hypertens. Rep. 2013; 15: 160-166.

28. Converse R.L., Jacobson T.N., Toto R.D. et al. Sympathetic overactivity in patients with chronic renal failure. N. Engl. J. Med. 1992; 327: 1912-1918.

29. Rahman S.N., Abraham W.T., Van Putten V.J., Hasbargen J.A., Schrier R.W. Increased norepinephrine secretion in patients with the nephritic syndrome and normal glomerular filtration rates: Evidence for primary sympathetic activation. Am. J. Nephrol. 1993; 13: 266-270.

30. Pickering T.G., Shimbo D., Haas D. Ambulatory blood pressure monitoring. N. Engl. J. Med. 2006; 354: 2368-2374.

31. Stolarz K., Staessen J.A., O’Brien E. Night-time blood pressure dipping into the future? J. Hypertens. 2002; 20: 2131-2133.

32. London G.M., Pannier B., Guerin A.P., Marchais S.J., Safar M.E., Cuche J.L. Cardiac hypertrophy, aortic compliance, peripheral resistance, and wave reflection in end-stage renal disease. Comparative effects of ACE inhibition and calcium channel blockade. Circulation 1994; 90: 2786-2796.

33. Tudor N.M., Navajas Martinez M.F., Mitrea A., Moţa E. Is non dipping hypertension associated with dyslipidemia, type 2 diabetes or chronic kidney disease? Rom. J. Diabetes. Nutr. Metab. Dis. 2013; 3: 331-337.

34. Liu M., Takahashi H., Morita Y. Non-dipping is a potent predictor of cardiovascular mortality and is associated with autonomic dysfunction in haemodialysis patients. Nephrol. Dial. Transplant. 2003; 18:563-569.

35. Pluta A., Stróżecki P., Krintus M. et al. Left ventricular remodeling and arterial remodeling in patients with chronic kidney disease stage 1-3. Ren. Fail. 2015; 37: 1105-1110.

36. Ligtenberg G., Blankestijn P.J., Oey P.L. et al. Reduction of sympathetic hyperactivity by enalapril in patients with chronic renal failure. N. Engl. J. Med. 1999; 340: 1321-1328.

37. Agarwal R., Andersen M.J. Correlates of Systolic Hypertension in Patients With Chronic Kidney Disease. Hypertension 2005; 46: 514-520.

38. Portaluppi F., Montanari L., Ferlini M., Gilli P. Altered circadian rhythms of blood pressure and heart rate in non hemodialysis chronic renal failure. Chronobiol. Int. 1990; 7: 321-327. 